\title{
Sheltered Employment and Mental Health in Britain: Remploy c.1945-1981
}

\author{
Andy Holroyde
}

\section{INTRODUCTION}

The history of mental health provision is now firmly established as a major area of research. The traditional focus on the asylum has also now been complemented with examinations of what went on outside its walls, and the focus on the history of the institution, likewise, has been complemented by attempts to give voice to its service users. ${ }^{1}$ Though research has tended to remain focused on the Victorian heyday of the asylum, studies which examine developments in mental health provision over the twentieth century have also appeared. ${ }^{2}$ The process of deinstitutionalisation which occurred after the Second World War has attracted attention from both historians and social policy analysts. ${ }^{3}$ Such considerations have focused on the key legislation passed in the period, particularly the Mental Health Act, 1959, and have presented an overall narrative of the move from residential institutions to community care, with a general conclusion that factors such as financial stringencies prevented the fulfilment of the objectives espoused by policymakers in this

\footnotetext{
A. Holroyde $(\square)$

University of Huddersfield, Huddersfield, UK

e-mail: Andrew.Holroyde@hud.ac.uk

(C) The Author(s) 2020

S. J. Taylor and A. Brumby (eds.), Healthy Minds

in the Twentieth Century, Mental Health in Historical Perspective, https://doi.org/10.1007/978-3-030-27275-3_6
}

113 
process. ${ }^{4}$ As John Welshman noted, however, the roles of the various institutions which together formed this community of care in the postwar period, such as hostels, special schools and occupation centres, have remained largely neglected by historians. ${ }^{5}$ Welshman himself began to remedy this with a preliminary exploration of the hostel system in the post-war period. ${ }^{6}$ In the conclusion to this piece, Welshman called for further work examining the system of community care. ${ }^{7}$ Responding to this call, this chapter seeks to provide a similar preliminary exploration of a further component of community care in the form of sheltered employment, chiefly that provided by Remploy.

The importance of employment to mental well-being and in the rehabilitation process of mental hospital patients has been noted by historians and social policy analysts. Employment within such institutional care for those with mental health conditions or learning disabilities has also been examined as part of the treatment provided. Historians have recognised the potential for such employment to be a positive experience for patients, providing, for example, a potential means to progress through the rehabilitation process, gain increasing independence and offer a source of friendship and informal care. ${ }^{8}$ That employment could have a 'darker side as an instrument of punishment, imposed redemption and atonement, exploitation and a means of control' has also been recognised. ${ }^{9}$ The provision of employment for patients once they had left such institutions was a key part of the transition to community living. Sheltered employment was an important aspect of this for those unable to secure work in open employment and represented something of a halfway house between the residential institution and the community in the promotion of 'healthy minds' for the mentally-ill. ${ }^{10}$

Remploy itself has received only scant attention from historians with limited references to its role in post-war disability employment provision. There were a range of voluntary organisations providing sheltered employment before the outbreak of the Second World War. Some schemes provided training or limited employment in residential settings such as St. Dunstan's, which was established in 1915 and did much to aid blind ex-servicemen, and the Star and Garter Home for Disabled Soldiers and Sailors, opened in 1916. ${ }^{11}$ More ambitious schemes involved whole sheltered communities of disabled ex-servicemen, such as the Enham Village Centre settlement, which combined a rural environment with training and some employment. ${ }^{12}$ The majority of schemes involved work in workshops or factories, the largest of which 
were the Lord Robert's Memorial Workshops. Established following the Boer War, they expanded during the First World War and at the end of 1919 employed over 600 men in several workshops around the country. ${ }^{13}$ Though likely preferable to unemployment, such workshops could be less than ideal for workers and were run on very slight budgets owing to their reliance on continued public generosity. ${ }^{14}$ Following the First World War, the British government did provide such charitable organisations with some limited financial support under the Ministry of Labour's 'Scheme of Grants'. ${ }^{15}$ During the interwar period, the Ministry paid these grants to 'thirty separate enterprises', which Deborah Cohen suggested probably employed around 2000 workers, 'only a fraction of those who according to the government's figures needed work'. ${ }^{16}$ At the close of the Second World War, there remained a number of voluntary providers of sheltered employment still in operation, though such provision was noted by the Ministry as being 'meagre and inadequate'. ${ }^{17}$

Remploy was established by the British government as part of the provision of the Disabled Persons (Employment) Act, 1944. The aim of the company was to provide sheltered employment on a national scale for those 'severely disabled people' who were considered unable to gain work in the open employment market. In a similar fashion to the nationalised industries, Remploy was run by a Board of Directors selected by the Ministry of Labour, who handled the day-to-day business of the company, while overall policy was directed by the Ministry. The company was intended to be as financially self-supporting as possible with any losses funded by the Treasury. A period of rapid expansion following the opening of the first Remploy factory in Bridgend in 1946 resulted in Remploy employing over 6000 disabled people across 91 factories by $1953 .{ }^{18}$ The number of employees steadily grew over the subsequent decades with Remploy remaining the dominant provider of sheltered employment in the post-war period. This began to change in the 1980s, in response to the fundamental changes to the welfare state which occurred and the increasing desire to promote the inclusion of disabled people in open or 'mainstream' employment. Remploy factories began to be closed down and replaced by Remploy 'branches' on the high street which focused on providing employment services to support those with disabilities or health conditions into mainstream employment. Remploy's transition from sheltered employment to employment services provider was finally completed with the closure of the remaining Remploy factories in 2013. Further change occurred when, in April 
2015, Remploy left government ownership. Continuing to provide specialist employment services, Remploy is, at the time of writing, owned by Maximus, an international provider of health and employment services, and Remploy employees themselves who hold a twenty per cent stake in the company. ${ }^{19}$

Though it was not the only form of sheltered employment available, with both voluntary organisations and Local Authorities also providing such services, Remploy was the majority provider. Owing to this and its place as the central government provider of sheltered employment, the company has, in contrast to the range of other organisations, left a significant imprint in the archives. This chapter will draw upon the wealth of material relating to the company located in the National Archives, as well as some archival material retained by the company itself. Remploy was initially called 'The Disabled Persons Employment Corporation', with its factories referred to as 'British Factories'. The name Remploy was in use from 1946 and officially adopted in 1949, though reference to the 'Corporation' continued for some years after this. In the interests of clarity, the term 'Remploy' will be used here. In terms of terminology in this chapter, the use of terms such as 'disability', 'disabled people', 'severely disabled people', 'Section I and II disabled people', 'mentally disabled people' and 'physically disabled people' solely reflects the specific historic bureaucratic categories applied to people during the period examined here and are not intended to reflect lived experience or personal/group identity. The term 'mentally disabled' is used frequently as a historic term which refers to a specific bureaucratic category which covered all forms of mental illness or learning disability and meant that a person was eligible for work in one of Remploy's factories. This chapter also includes occasional instances of use of what is now considered derogatory language in direct quotation from primary sources. This is done purely in the interests of historical accuracy in order to reflect the nomenclature of the period and is not intended to condone any current use of such terms.

This chapter will explore the role played by Remploy as the largest provider of sheltered employment in the provision of community care in the post-war period. The composition of Remploy's workforce has yet to be examined in detail and has thus largely been taken for granted by academics across disciplines as being simply 'disabled people' or 'severely disabled' people. ${ }^{20}$ The popular viewpoint meanwhile, espoused by Remploy itself and regularly featured in media reports on the company, has suggested that Remploy was created to cater for those injured 
as a result of the Second World War. ${ }^{21}$ There is a general assumption, therefore, that in the immediate post-war period Remploy catered solely for so-called physically disabled people. Yet by the mid-1980s, $40 \%$ of Remploy's employees were those with 'some form of mental or nervous handicap'. ${ }^{22}$ This move from so-called physical to non-physical or 'mental' disability in the company's employees is understood by Remploy itself to be a key feature in the development of the company, yet there is no understanding of how this occurred beyond the assumption that the 1959 Mental Health Act instigated the change. ${ }^{23}$ This development has similarly remained unexplored in considerations of Remploy and disability employment provision among academics. This chapter will therefore attempt to clarify the position of Remploy in the employment provision for mentally disabled people and to add this to our understanding of the development of sheltered employment in the post-war period. To do so it will consider first the impact of the 1959 Mental Health Act upon Remploy, to determine if this did indeed mark a turning point in the company as has been assumed. It will then consider the place of mentally disabled people within Remploy and whether the company adapted to reflect an increasing number of such employees.

\section{The Impact of the 1959 Mental Health}

\section{Act-A Turning Point?}

The central legislative impetus for the move from institutional to community care for the mentally-ill was the Mental Health Act, 1959. One change instigated by the Act was that the former mental hospital patients became able to register as disabled in line with the Disabled Persons (Employment) Act and thereby become eligible for a place in a Remploy factory. ${ }^{24}$ Though it has been suggested by historians that the legal changes imposed by the 1959 Act were not matched by practical application at the local level, the case of sheltered employment in this assessment has not been examined until now. ${ }^{25}$ As noted, there has been an assumption that in the immediate post-war period, Remploy catered solely for the physically disabled until the 1959 Act resulted in the introduction of mentally disabled people. It is apparent, however, that Remploy had always included people designated as 'disabled' because of 'mental illness' or 'mental disability'. To understand this, it is first necessary to understand the process by which disabled people became eligible for a place in a Remploy factory. 
Entry to Remploy involved a specific process which all potential workers had to follow. The first step to entering a Remploy factory was registering as a disabled person on the Disabled Persons' Employment Register. $^{26}$ This was the voluntary mechanism established by the Disabled Persons (Employment) Act, 1944, for gaining access to any of its provisions, including Remploy. The registration process involved a person fulfilling a number of criteria and certain exclusions applied. First, a person had to be considered disabled in accordance with the definition of the Act, which stated that:

'Disabled person'- means a person who, on account of injury, disease or congenital deformity, is substantially handicapped in obtaining or keeping employment, or in undertaking work on his own account, of a kind which apart from that injury, disease or deformity would be suited to his age, experience and qualifications. ${ }^{27}$

Beyond this general definition, the Act further stipulated that a person's disability must be likely to last for six months or more; that the person must be at least 14 years old; that they be resident in Great Britain; and that they be willing to undertake the training or employment offered. ${ }^{28}$ Those disqualified from registration included prisoners, full-time hospital patients and those deemed to be of 'bad character'. ${ }^{29}$ Mentally disabled people were therefore always included in the broad definition of disability contained in the Act. There were, however, some further exclusions which applied to disabled people who were subject to treatment under the Lunacy and Mental Treatments Acts. ${ }^{30}$ The scope of such exclusions was given further consideration by the Ministry of Labour in 1945, following calls from the Board of Control and the London County Council for clarity regarding whether those 'mental defectives' receiving treatment, particularly in the case of those living outside institutions, were eligible for registration or not. ${ }^{31}$ Following a process of consultation between the Board of Control, the Ministry of Health and the Ministry of Labour, it was finally agreed that registration was possible for those under treatment or supervision under the Mental Deficiency Act, provided such persons were considered likely to be able to gain and keep employment. ${ }^{32}$ Exclusion from registration continued to apply to those who were resident in mental hospitals or institutions unless they were individually authorised to be absent on licence. ${ }^{33}$

Having registered upon the Disabled Persons' Employment Register, a disabled person was then assessed and designated as being either 
'Section I' or 'Section II'. Section I disabled people were those considered able to secure work in open employment and represented the majority of those registered. The Section II designation applied to those considered too 'severely disabled' to access open employment, and thereby as requiring sheltered employment provision. Those designated as Section II were therefore eligible for a place in Remploy, and it was from this pool of disabled people that Remploy could recruit its factory workers. Eligibility was therefore determined on the basis of the impact of a person's disability upon their employment prospects, and as such, mentally disabled people were able to register and become eligible for Remploy. The inclusion of such cases in Remploy was always expected, as the Ministry of Labour made clear when considering the issue of placing those with 'psychiatric disorders' in employment in 1945. ${ }^{34}$

At no time in its existence did Remploy employ all Section II, and therefore theoretically eligible, disabled people, but rather selected a limited number of employees from this pool of potential recruits. As Remploy began to expand in the late 1940s, it is apparent that Remploy did indeed include those with mental disabilities within its disabled workforce. Unfortunately, there is no breakdown of what was termed the 'disability mix' within the company extant for the early period of Remploy's operation. Some localised examples do attest to the inclusion of mentally disabled people in the workforce, with the Halifax Remploy factory including an individual with 'low mentality' among its employees in 1948, and with the Barking Remploy factory noting that it had a dozen employees suffering 'Neurosis' among its workers. ${ }^{35}$ Furthermore, a guide for Remploy factory managers published and distributed by the company in 1949 made reference to those with 'mental disabilities' as one category of disabled employee factory managers were dealing with. ${ }^{36}$

A full company breakdown of its disabled employees comes from December 1954, by which time Remploy had completed its initial factory expansion, with 91 factories in operation employing some 6433 disabled people. ${ }^{37}$ Of these disabled employees, some 530 were classified as having a 'mental disability' in terms of neurosis, psychoneurosis or 'nervous or mental disorders'. ${ }^{38}$ Remploy was therefore employing a significant number of people, a little over $8 \%$ of its workforce, with mental disabilities five years prior to the passing of the 1959 Act. It is apparent therefore that the 1959 Act did not introduce mentally disabled people into Remploy and that the assumption that the company catered 
exclusively for the physically disabled in the immediate post-war period does not reflect the reality.

The question then is what impact the 1959 Act did have upon Remploy. During discussion of the Act in the House of Commons, anxiety was expressed by the Labour MP Edward Mallalieu, when querying what was to become of those deinstitutionalised in terms of employment and whether there would be specialist sheltered employment for such cases 'on the Remploy model'. ${ }^{39}$ In the House of Lords, the following year, it was suggested that Remploy should take a central role in providing sheltered employment for those deinstitutionalised. ${ }^{40}$ Remploy was not something that required setting-up, it was already in the community and was already employing people considered 'severely disabled' due to mental illness or disability. One might be forgiven, therefore, for assuming that they would be greatly utilised as part of the move to community care following the 1959 Act. Remploy later described how it had taken a 'fair share of this burden' in terms of the policy of deinstitutionalisation, so that by 1964 ' $10 \%$ or our total disabled employees were suffering from mental disabilities'. ${ }^{41}$ However, when compared with the $8 \%$ of such cases a decade earlier, it is apparent that the Act did not lead to an immediate sea change in terms of recruitment policy and a sudden influx of such cases within Remploy, with an increase of only $2 \%$ over 10 years. Indeed, by December 1959, the figure was already approaching $9 \% .{ }^{42}$

With Remploy already including a significant proportion of workers with mental disabilities, it appears that the focus for the company following the passing of the Act was on a cautious consideration of how the company might cater for the newly eligible former mental hospital patients who may have had more 'severe' mental health conditions than the company had yet been asked to accommodate. As the Executive Director of Remploy noted, it had previously been the policy in Remploy that 'serious mental cases were not employed'. ${ }^{43}$ The initial response to the 1959 Act was therefore the undertaking of an experiment in employing 'serious mental cases' in the form of mental hospital patients suffering from schizophrenia. The experiment was conducted in 1960 in conjunction with the Ministry of Labour and the Medical Research Council. ${ }^{44}$ This involved the employment of a small number of such 'serious' cases across a group of factories. ${ }^{45}$ Thus, by April 1960, there were three such persons employed in the Croydon Remploy factory and one in the Barking factory, with two more awaiting employment in the Park Royal factory and Southampton factory, respectively. ${ }^{46}$ 
The following month saw the extension of the experiment with a further small intake at the Bermondsey factory and the inclusion of two former patients from the Long Grove Hospital at the Radcliffe factory. ${ }^{47}$ At the meeting of the Remploy Board of Directors in which the experiment was discussed, one member expressed her surprise 'that we were employing schizophrenic patients in our factories' ${ }^{48}$ It was explained by the Executive Director that this was part of a limited experiment and that the 'persons recruited by Remploy were very carefully selected'. ${ }^{49}$ This selection appears to have included advice from medical experts, as well as a series of interviews and discussions with several management levels within Remploy, with careful consideration of each case. ${ }^{50}$ The Managing Director noted that those employed were 'doing very well'. ${ }^{51}$ Similarly, the Executive Director was able to claim that those recruited 'had proved to be very good workers'. ${ }^{52}$ The representative of the Ministry of Labour at the meeting further explained that the Minister himself had received a special report on the progress of the experiment thus far and was 'very pleased and heartened with the action taken'. ${ }^{53}$ Indeed, the experiment was referenced in the House of Commons in July 1961 with Mr William Morgan, the Conservative MP for Denbigh noting:

Remploy factories do not remain static in their attitude to employment. I was gratified to learn from a recent report that the Remploy factories have, by arrangement with my right hon. Friend the Minister of Labour, taken in a small number of patients suffering from the effects of schizophrenia. This effort to give mentally disordered persons a place in the working life of the community deserves every sympathy and encouragement. The rehabilitation of these particularly unfortunate disabled persons is a challenging experiment, and it must be a satisfaction to us all that the results, according to the report, have so far been very encouraging. ${ }^{54}$

Such 'experimentation' in using employment to make 'sick' minds 'healthy' was not limited to Remploy, with sheltered employment run by Local Authorities and voluntary institutions also responding to the change in eligibility for registration brought on by the 1959 Act. In 1960, for example, the City of Leeds introduced a sheltered works programme in its parks department, while the following year the Industrial Therapy Organisation in Bristol launched an 'experimental 
scheme' providing 'special supervision' to a group of ex-mental hospital patients in open industry. ${ }^{55}$ In addition to this, the Industrial Therapy Organisation established a car-wash scheme which 'was operated entirely by mental patients, many of whom had been in psychiatric hospitals for a number of years' ${ }^{56}$ In a report on the scheme by the National Advisory Council on the Employment of the Disabled (NACED), established by the Disabled Persons (Employment) Act to oversee the progress of its provision, the car wash was 'running at a profit and well patronised by the Bristol public' with the suggestion that this had contributed to a positive change 'in the attitudes of the public towards the mentally disordered'. ${ }^{57}$ As with Remploy, it was noted that for all such schemes 'the workers involved were specially selected patients'. ${ }^{58}$

The Mental Health Act did not, therefore, lead to a sea change in who was recruited by Remploy and did not instigate a sudden influx of former mental hospital patients into the company. Its impact in the immediate term was rather a limited experiment with carefully selected cases of those newly eligible for Remploy. The Act does appear, however, to have supported an existing longer-term trend of increasing numbers of mentally disabled people registering upon the Disabled Persons Employment Register and thereby increasing the proportion of such cases within Remploy's recruitment pool. In 1963, people with 'mental illness or mental handicap' represented $14 \%$ of the Section II register; by 1973, this had increased to $20 \%$ and by 1978 had reached $25 \% .{ }^{59}$ This increase was similarly reflected in the proportion of those with mental disabilities employed by Remploy. By 1974, the proportion of employees with mental disabilities in Remploy had increased to $17 \%$, making it the largest disability 'grouping' in the company, and by 1978 had increased again to $20 \% .{ }^{60}$ This trend was well recognised by both Remploy and the government. During a debate in the House of Commons on the employment of disabled people in 1972, it was noted that 'mental and nervous conditions are of growing significance'.61 In its investigation of sheltered employment the following year, the Department of Employment, previously the Ministry of Labour, suggested this trend was a result of both 'modern techniques of care and attention' by which 'mentally handicapped or mentally ill people are enjoying a longer and full life' as well as 'present mental health policies...aimed at minimising in-patient treatment' ${ }^{62}$ The result was that 'more and more mentally handicapped and mentally ill people are becoming available for sheltered employment'. ${ }^{63}$ 
A significant change clearly occurred in Remploy's disability mix over the period considered in this chapter, with a steady increase in the number of mentally disabled people as a proportion of both those employed by Remploy and in terms of those eligible to apply for a place with the company. ${ }^{64}$ The Mental Health Act, 1959, and the policy of deinstitutionalisation are therefore best understood as contributors to a longerterm trend in terms of eligibility for sheltered employment, which Remploy steadily increasingly drew upon.

\section{Mental Disability Within Remploy}

With Remploy employing an increasing number of mentally disabled people over the course of the period examined in this chapter, it is important to consider the impact such a change had upon the company. This chapter will now consider the place of those with mental disabilities in Remploy and whether the company adapted to reflect the changes in who it was employing.

As previously noted, Remploy did not simply employ all those eligible under the Disabled Persons (Employment) Act, designated as being Section II. Rather, the company selected those it wished from the available Section II pool of candidates. From the beginning, the Remploy Board of Directors were clear that they felt that the primary purpose of Remploy was to provide 'genuine employment' and establish a viable long-term business for its severely disabled employees. There was to be no place for either charity or simple occupational therapy. ${ }^{65}$ The 'treatment' or 'rehabilitation' provided by Remploy was in terms of the understood benefits of worthwhile employment for the individual. The aim of the company was 'to provide productive and worthwhile work' in an environment which resembled a 'normal' industrial operation as closely as possible. ${ }^{66}$ The 1956 report of the Committee of Inquiry on the Rehabilitation, Training and Resettlement of Disabled Persons (Piercy Report), established to review the progress of the provisions of the Disabled Persons (Employment) Act, emphasised the importance of productivity and the concept of genuine employment in distinguishing sheltered employment provision from purely occupational welfare. ${ }^{67}$ The report of the Royal Commission on the Law Relating to Mental Illness and Mental Deficiency (Percy Commission) the following year endorsed the application of this principle 'with regard to mentally handicapped or disabled patients' ${ }^{68}$ Sheltered employment provision such as Remploy was 
therefore to provide employment for those capable of undertaking work with a degree of productivity. The chief aspect considered in recruitment to Remploy was not therefore a person's disability per se, but rather the potential productivity of the applicant. In short, Remploy factory managers were primarily concerned with recruiting the most productive workers from the available Section II pool of candidates, regardless of the person's particular disability. As such, those with mental disabilities were considered for work in a Remploy factory by this same measure, with only those capable of undertaking the factory work required being recruited and retained by the company.

In following this principle, Remploy employed workers with a wide range of disabilities. The records for the company reveal that consideration was regularly given to potential issues involved in the employment of people with different disabilities. In terms of mentally disabled people specifically, there were regular questions raised about the benefits of integration. The notion that mentally disabled people should be segregated within sheltered employment had been raised from the very beginning of Remploy, with consideration about the placing of 'psycho-neurotics' in 1945. ${ }^{69}$ There was broad agreement within the Ministry of Labour at that time that in such cases 'segregation is undesirable'. ${ }^{70}$ Such a policy was subsequently adopted by Remploy, with the only case of segregation along the lines of disability being the establishment of a number of dedicated Tuberculosis (TB) factories owing to the danger of infection. As such, in the case of Remploy, mentally disabled people both before and after the passing of the 1959 Mental Health Act were not segregated.

In the wider field of sheltered employment, things were not as clearcut. Unlike Remploy, sheltered employment provided by voluntary organisations could often be limited to particular groups of disabled people. This reflected the various purposes and 'causes' to which these organisations were devoted. In the most obvious example, sheltered employment in TB sanatoria was, of course, available only for those with TB. Similarly, those sheltered workshops run by the British Legion provided only for the ex-servicemen which the charity was established to support, while the workshop run by the Ayrshire Society for the Deaf, as its name suggests, provided sheltered employment only for the deaf. ${ }^{71}$ In the case of mental illness, in 1945 only one organisation explicitly focused on this group, Thermega Limited, which provided employment for 36 disabled men suffering from 'Neurosis, psychosis and associated diseases'. ${ }^{72}$ By 1965, a Ministry of Labour list of 'approved independent 
charitable sheltered employment providers' included several which were explicitly devoted to mentally disabled people. This included the Industrial Therapy Organisation which employed 68 'mainly mentally handicapped men and women' and the Camphill Village Trust, which employed 183 'mentally handicapped men and women' across three sites. $^{73}$ In terms of Local Authorities too, the NACED noted in 1965 that several Authorities had followed Leeds in providing sheltered employment programmes specifically aimed at mentally disabled people. ${ }^{74}$

The policy view remained, however, that integration was generally preferable wherever possible. This view was endorsed by the Secretary of State for Employment and Productivity in 1968, when he expressed his belief that 'sheltered workshops should cater as Remploy does, for both the mentally and physically handicapped' ${ }^{75}$ This was reiterated under the following government in 1971, with the Under-Secretary of State for Employment replying to a query regarding the possibility of providing sheltered employment exclusively for the 'mentally handicapped', that 'sheltered work is generally best provided in workshops catering for all kinds of severely disabled people'. ${ }^{76}$ The Department of Employment's detailed examination of the sheltered employment field in 1973 argued too that it was desirable that such provision avoided 'arrangements whereby people are segregated into particular categories of disability' and made 'integrated arrangements as far as it is possible to do so'. ${ }^{77}$ The Department recognised, however, 'that broad policy contains certain areas of difficulty and uncertainty, especially in the fields of mental handicap and mental illness; and there may sometimes be good reason for separate measures for particular disabilities in certain circumstances' ${ }^{78}$ Such a case occurred in 1976, with a proposal, at the request from the Department of Employment, for Remploy to open a factory entirely for some 90 mentally-ill patients in Surrey. ${ }^{79}$ This was not, however, due to any belief that this was inherently preferable; rather, it was owing to practicalities and location. ${ }^{80}$ The issue being that there were 100 such cases in hospitals in the Epsom area all deemed to be 'suitable for sheltered employment'. ${ }^{81}$ Rather than 'dispersing them around the country, with all the problems that would be involved in finding work and accommodation', the better option was believed to be to 'open a factory, solely for them in the immediate location'. ${ }^{82}$ This project was not to come to fruition and it remained the case that mentally disabled people remained integrated into Remploy as policy. Arguably, this policy of integration may have had a positive effect on the minds of those 
suffering from mental illnesses, by offering them regular employment and the opportunity to assimilate into a broader community.

One consequence of this policy of integration was that mentally disabled people would have to essentially 'fit-in' with the normal 'flow' of a Remploy factory in the same way as any other disabled employee. The question is therefore whether the increasing proportion of employees with mental disabilities resulted in any changes to the way Remploy operated. In 1964, Remploy's personnel director spoke at an international conference on social psychiatry in London on the topic of 'practical problems on the employment of the mentally handicapped' ${ }^{83}$ Such discussions were not unique to considerations of mental disability, with regular reflections from the company on employment 'issues' relating to a range of disabilities within the company occurring throughout the period. However, the increasing number of mentally disabled employees within Remploy does seem to have led to greater consideration of the implications raised, with a belief that this offered particular challenges for factory management.

In 1974, responding to concerns expressed by a group of factory managers, it was decided by Remploy to undertake 'teach-ins' across the company, with factory managers and doctors invited for group discussion and instruction in order 'to increase our skill in handling mentally disabled people' ${ }^{84}$ At a meeting of the Remploy Board of Directors discussing the 'teach-ins', the Managing Director 'stressed the importance of these, with the increasing numbers of mentally disabled in Remploy, and the need for even experienced factory managers to have more guidance'. ${ }^{85}$ It was explained that the key point raised during the teach-ins 'which has already come across very forcibly (and which has been raised before many times by works managers) is the need to improve the ratio of supervisory staff to disabled employees, especially where mentally disabled people are concerned'. ${ }^{86}$ This question of additional supervision appears to have been the main conclusion from the sessions, with no commitment to take further action. ${ }^{87}$ The only hint of any notion of instigating systemic change in the way Remploy operated was a remark by one Board member that having attended one of these teach-ins, 'he had become very much aware that the Company might have to change some points of its basic policy of employment if mental illness were to be catered for' ${ }^{88}$

There was, therefore, to be no meaningful consideration of fundamental change to Remploy until the early 1980s with two internal reports examining the issue. The first of these was a wide-ranging report considering the fundamental purpose of Remploy and its "criteria of 
success' ${ }^{89}$ As part of its findings, the report noted that since its establishment, the key development in terms of Remploy's recruitment pool was the significant change 'from physical to mental disability'. ${ }^{90}$ It then echoed the conclusions from the 'teach-ins', claiming that there remained a 'generally held view' in the company that an 'increase in the numbers of supervisory staff to disabled employees' was necessary in order 'to maintain an acceptable level of productivity and efficiency'. ${ }^{91}$ The recommendation of the report was that 'a limit should be placed on the numbers of mentally disabled; if this cannot be controlled serious consideration would have to be given to establishing separate units within Remploy for the employment of the mentally disabled'. ${ }^{92}$ As a result of this report, a working party was formed to fully examine the issue of the so-called disability mix in Remploy. The report explained:

The chief aspect of disability mix on which Remploy Managers have fairly firm opinions is that of mental disability. Maintaining an acceptable balance between employees with mental and nervous disabilities and those with physical handicaps is regarded as a major problem and managers are keenly interested therefore in trends in disability mix. ${ }^{93}$

The report noted the expectation that the trend of an increase in the 'proportion of mentally disabled' would continue. ${ }^{94}$ Ultimately, however, it rejected the idea of establishing any limit or set quota, highlighting that there was already a 'smaller proportion of mentally handicapped people' working in Remploy than were on the Disabled Persons Register. ${ }^{95}$ The report further argued that while there were concerns expressed by some factory managers, there were many examples where there were no issues with integration within factories. ${ }^{96}$ The report concluded that it was ultimately up to factory managers to deal with any issues which arose on a case-by-case basis. The solutions proposed were focused on supporting this with better training for managers. ${ }^{97}$ This was not to be the end of the issue, with the report suggesting further consideration would be needed regarding how the company should readjust to reflect the increasing proportion of mentally disabled employees. ${ }^{98}$ Such considerations were to wait until later in the decade when changes in the welfare state, manufacturing industry and perceptions of sheltered employment itself were to lead to more fundamental changes to Remploy. While concerns were frequently expressed, therefore, and the issue of changes to Remploy examined carefully, action in the period 
considered in this chapter was limited to the offer of more support for factory management to manage their employees effectively.

\section{Conclusions}

Contrary to both the popular and scholarly understanding of Remploy, this chapter has illustrated that the inclusion of mentally disabled people within the company's disabled workforce was not a sudden result of the 1959 Mental Health Act but was a feature of the company from its very beginning. It was always expected that Remploy would employ those considered 'severely disabled' in line with the Disabled Persons (Employment) Act, 1944 owing to mental illness or disability and it is apparent that they did so. The promotion of 'healthy minds' through productive work in Remploy was thus available to mentally disabled people. The immediate impact of the 1959 Act was the limited inclusion of some of the more 'serious' cases of mental hospital patients the company might be expected to employ, with similar experiments undertaken by other organisations. The most significant effect of the Act was in supporting an existing trend in increasing numbers of mentally disabled people entering Remploy's recruitment pool. While this change in the company's 'disability mix' did provoke some concern among factory management, there was to be no serious consideration of whether it justified a fundamental rethink of how Remploy operated until the early 1980s. As such, mentally disabled people in Remploy were recruited and employed in the factories on the same basis as all disabled workers. Individual productivity and how well a person could 'fit-in' with the operations of the given factory would determine their access to Remploy. In offering such conclusions, the nature of this chapter as a preliminary examination bears repeating. Further research into the place of sheltered employment within the process of deinstitutionalisation and into the experiences of mentally disabled people across the range of sheltered employment providers would contribute enormously to our understanding of how employment was considered to aid in the promotion of 'healthy minds'.

\section{Notes}

1. Peter Bartlett and David Wright, eds., Outside the Walls of the Asylum: The History of Care in the Community 1750-2000 (London: Athlone Press, 1999); Lindsay Brigham et al., eds., Crossing Boundaries: Change and 
Continuity in the History of Learning Disability (Kidderminster: BILD Publications, 2000).

2. Mathew Thomson, The Problem of Mental Deficiency: Eugenics, Democracy, and Social Policy in Britain, c. 1870-1959 (Oxford: Clarendon Press, 1998); Pamela Dale and Joseph Melling, eds., Mental Illness and Learning Disability Since 1850 (Abingdon: Routledge, 2006).

3. Kathleen Jones, Mental Health and Social Policy 1845-1959 (London: Routledge \& Kegan Paul, 1960); Kathleen Jones, A History of the Mental Health Services (London: Routledge \& Kegan Paul, 1972); Julian Leff, ed., Care in the Community: Illusion or Reality? (Chichester: Wiley, 1997); Helen Lester and Jon Glasby, Mental Health Policy and Practice (2nd edition) (Basingstoke: Palgrave Macmillan, 2010); Kelley Johnson and Rannveig Traustadottir, eds., Deinstitutionalization and People with Intellectual Disabilities: In and Out of Institutions (London: Jessica Kingsley, 2005).

4. Lester and Glasby, Mental Health Policy and Practice, 30-31; John Welshman, "Rhetoric and Reality: Community Care in England and Wales 1948-74," in Outside the Walls of the Asylum, eds. Bartlett and Wright; John Carrier and Ian Kendall, "Evolution of Policy," in Care in the Community, ed. Leff, 3-20; Jones, Mental Health and Social Policy, 153-206; Jones, A History of the Mental Health Services, 306-352; Alan Roulstone and Simon Prideaux, Understanding Disability Policy (Bristol: Policy Press, 2012), 36-39.

5. John Welshman, "Inside the Walls of the Hostel, 1940-74," in Mental Illness and Learning Disability Since 1850, eds. Dale and Melling, 200.

6. Ibid., 200-223.

7. Ibid., 219-220.

8. Ibid., 216-217.

9. Ibid.

10. The National Archives (Henceforth TNA), LAB 20/1429, Department of Employment, Sheltered Employment: A Draft Consultative Document (October 1973), 11-14.

11. For more on these, see Julie Anderson, War, Disability and Rehabilitation in Britain: 'Soul of a Nation' (Manchester: Manchester University Press, 2011), 49-55; Julie Anderson and Neil Pemberton, "Walking Alone: Aiding the War and Civilian Blind in the Inter-War Period," European Review of History 14, no. 4 (2007): 459-479.

12. For these schemes, see Village Settlements for Disabled Ex-Service Men Scheme, October 1917; "Village Settlements for the Disabled," The Lancet, 3 November 1917; "Reconstruction: Village Settlements for Disabled Ex-Service Men," Westminster Gazette, 9 November 1917all in the National Archives TNA, PIN 15/34; Village Centres Council, 
First Annual Report 1919, TNA, PIN 15/37; Minutes of Third Meeting, Committee on Employment of Severely Disabled Ex-Service Men (20 October 1920), TNA, PIN 15/36.

13. TNA, LAB 20/56 R.D.9, Inter-Departmental Committee on the Rehabilitation and Resettlement of Disabled Persons: Note by the Ministry of Pensions.

14. See Deborah Cohen, The War Come Home: Disabled Veterans in Britain and Germany 1914-1939 (Los Angeles: University of California Press, 2001), 112-114, for criticisms of sheltered employment generally. Anderson, Soul of a Nation, 27-28 presents a more positive assessment.

15. TNA, CAB 24/123/79, Cabinet Summary of the Report of the Committee Appointed to Consider the Employment of Severely Disabled Ex-Service Men (with special reference to Lords Roberts Memorial Workshops) (25 May 1921); TNA, PIN 15/34, Memo by Finance Department as to the Financial Position of the Lord Roberts Memorial Workshops; Cohen, The War Come Home, 44-46; Sir Smedley Crooke to Mr. E. Brown, Hansard (22 December 1938), vol. 342 cc. 3101-3w.

16. Cohen, The War Come Home, 45-46.

17. TNA, LAB 20/173, NACED: Sheltered Employment Committee, Report to the National Advisory Council on the Employment of the Disabled, N.A.C. 9 (10 May 1945).

18. TNA, BM 10/1, The Disabled Persons Employment Corporation Limited Later Remploy Limited: A Review of the Working of the Company During Its First Seven Years (March 1953), 34.

19. Remploy, "Our Business." https://www.remploy.co.uk/about-us/ our-business.

20. Jameel Hampton, "Discovering Disability: The General Classes of Disabled People and the Classic Welfare State, 1948-1964," The Historian 75, no. 1 (March 2013): 80; Linda Bryder, Below the Magic Mountain: A Social History of Tuberculosis in Twentieth-Century Britain (Oxford: Oxford University Press, 1988), 237; Sue Wheatcroft, Worth Saving: Disabled Children During the Second World War (Manchester: Manchester University Press, 2013), 168; Mark Hyde, "Sheltered and Supported Employment in the 1990s: The Experiences of Disabled Workers in the UK," Disability \& Society 13, no. 2 (July 1998): 200; Paul Bridgen and R. Lowe, Welfare Policy Under the Conservatives 1951-1964 (London: Public Record Office Handbooks, 1998), 262-263; Helen Bolderson, Social Security, Disability and Rehabilitation: Conflicts in the Development of Social Policy 1914-1946 (London: Jessica Kingsley, 1991), 109; Eda Topliss, Provision for the Disabled (Oxford: Wiley-Blackwell, 1979), 56; Matthias Reiss, Blind Workers Against Charity: The National League of the Blind of Great Britain and Ireland, 1893-1970 (London: Palgrave 
Macmillan, 2015), 139; Julie Anderson, “'Turned into Taxpayers': Paraplegia, Rehabilitation and Sport at Stoke Mandeville, 1944-56," Journal of Contemporary History 38, no. 3 (July 2003): 469; Colin Barnes, Disabled People in Britain and Discrimination (London: C. Hurst \& Company, 2000), 71; Anne Borsay, Disability and Social Policy in Britain Since 1750 (Basingstoke: Palgrave, 2005), 135; Pat Thane, Foundations of the Welfare State (2nd edition) (London: Routledge, 1996), 225.

21. Remploy "Who We Are," Remploy Website 2017. http://www.remploy. co.uk/info/20124/find_out_more/72/who_we_are; Remploy "Remploy's Journey," Remploy Website 2017. http://www.remploy.co.uk/downloads/ file/141/remploys_journeypdf; Nikki Fox, "What Are Remploy Workers Doing Now?" BBC News (31 November 2014). http://www.bbc.co.uk/ news/uk-29843567; Jason Beattie, "Hundreds of Axes Disabled Workers Still Jobless Two Years After Remploy Factory Closures," Mirror, 5 January 2015. http://www.mirror.co.uk/news/uk-news/hundreds-axed-disabled-workers-still-4919835; ITV Report, "Remploy's History as Specialist Disabled Employer Remembered as Final Factories Close," 31 October 2013. http://www.itv.com/news/2013-10-31/final-remploy-factory-closes/; Historic England, "Disability History: Disability, Rehabilitation and Work" (2017). https://historicengland.org.uk/research/inclusive-heritage/ disability-history/1945-to-the-present-day/disability-rehabilitation-and-work/.

22. TNA, BM 10/53, Remploy Limited, Remploy Facts (September 1986); TNA, BM 10/55, Remploy Limited, Who We Are (1994); TNA, BM 10/52, Remploy Limited, Remploy: Company Profile (1997); TNA, BM 10/57, Remploy Limited, Remploy: Planning Our Future (1998).

23. TNA, BM 10/2, R. E. Benjamin, A Brief Outline of the Birth and Early Development of Remploy Limited (May 1979), 26.

24. The Act had received an amendment in 1958, TNA, BM 10/2, Benjamin, Brief Outline of the Birth and Early Development of Remploy, 26.

25. Welshman, "Inside the Walls of the Hostel," 210.

26. Borsay, Disability and Social Policy, 135; Topliss, Provision for the Disabled, 49.

27. Disabled Persons (Employment) Act (1944) para 1.

28. Disabled Persons (Employment) Act (1944) para 7; Bolderson, Social Security, 117.

29. Bolderson, Social Security, 117. See also TNA, LAB 20/109.

30. Ibid.

31. TNA, LAB 20/212, Board of Control, Letter to Miss Hill MOL (27.11.1945); TNA, LAB 20/212, MOL, Letter to Mr. Bleakley, Board of Control (8 December 1945).

32. TNA, LAB 20/212, MOL, Disabled Persons (Employment)Act, 1944: Register of Disabled Persons (11 December 1945). 
33. TNA, LAB 20/212, MOL, Disabled Persons (Employment) Act, 1944: Registration of Patients of Mental Hospitals (13 December 1950); TNA, BM 3/7, Remploy Limited, Letter from Personnel Manager to St. Lawrence's Hospital Management Committee (6 January1958).

34. TNA, LAB 20/173, NACED Sheltered Employment Committee, Employment of Persons Suffering from Psychiatric Disorders (S.E.C. 9).

35. TNA, LAB 20/444, The Disabled Persons Employment Corporation Limited, Executive Director Report 36: Appendix B (18 November 1948); Fourth Report from the Select Committee on Estimates (April 1952) (162), Annex 9, 100.

36. TNA, BM 5/9, Remploy Limited, Factory Manager's Guide (1949).

37. TNA, BM 8/23, Remploy Limited, Managing Director's Report No. 30 (16 March 1955), Appendix L, The Disabled Persons Employment Corporation Limited later Remploy Limited: A Review of the Working of the Company during its First Seven Years (March 1953), 34.

38. TNA, BM 8/23, Remploy Limited, Managing Director's Report No. 30 (16 March 1955), Appendix L.

39. Mr. Mallalieu (26 January 1959), Hansard, vol. 598, cc. 822.

40. Lord Stonham (28 November 1960), Hansard, vol. 226 cc. 919-20.

41. TNA, BM 10/48, Remploy Limited, Company Objectives and Criteria of Financial Success (7 January 1980), Appendix No. 7; TNA, BM 10/2, Benjamin, A Brief Outline of the Birth and Early Development of Remploy Limited, 26.

42. TNA, BM 8/32, Remploy Limited, Managing Director Report No. 85: Appendix K (9 March 1960).

43. TNA, BM 8/2, Remploy Limited, Minutes of the One Hundred and Thirty-First Meeting of the Board of Directors (15 May 1957).

44. TNA, BM 10/2, Benjamin, A Brief Outline, 26; TNA, BM 8/32, Remploy Limited, Report of the Managing Director, No. 88 (May 1960).

45. TNA, BM 10/2, Benjamin, A Brief Outline, 26.

46. TNA, BM 8/32, Remploy Limited, Report of the Managing Director, No. 86 (April 1960).

47. TNA, BM 8/32, Remploy Limited, Supplement to Managing Director's Report No. 87 (11 May 1960); TNA, BM 8/32, Remploy Limited, Report of the Managing Director, No. 88 (May 1960).

48. TNA, BM 8/2, Remploy Limited, Minutes of the One Hundred and SixtyFifth Meeting of the Board of Directors (18 May 1960).

49. Ibid.

50. TNA, BM 8/32, Remploy Limited, Report of the Managing Director, No. 88 (May 1960).

51. TNA, BM 8/32, Remploy Limited, Report of the Managing Director, No. 86 (April 1960). 
52. TNA, BM 8/2, Remploy Limited, Minutes of the One Hundred and SixtyFifth Meeting of the Board of Directors (18 May 1960).

53. TNA, BM 8/2, Remploy Limited, Minutes of the One Hundred and SixtyFifth Meeting of the Board of Directors (18 May 1960).

54. Mr W.G. Morgan, Hansard (12 July 1961), vol. 644 cc. 486.

55. TNA, LAB 20/1429, DE, Sheltered Employment: A Draft Consultative Document (October 1973), 13-14; TNA, LAB 20/1211, NACED Sheltered Employment Committee: Provision of Sheltered Employment for the Mentally Ill in Private Firms: S.E.C. 114 (November 1965).

56. TNA, LAB 20/1211, NACED, Minutes of Meeting (19 January 1966).

57. Ibid.

58. Ibid.

59. TNA, BM 10/48, Remploy Limited, Company Objectives and Criteria of Financial Success (7 January 1980), Appendix No. 7.

60. Ibid.

61. Mr. Dudley Smith (21 June 1972), Hansard, vol. 839 c. 680.

62. TNA, LAB 20/1429, DE, Sheltered Employment: A Draft Consultative Document (October 1973), 33-34.

63. Ibid., 33-34.

64. TNA, BM 10/48, Remploy Limited, Company Objectives and Criteria of Financial Success (7 January 1980), 21.

65. TNA, BM 10/1, The Disabled Persons Employment Corporation Limited Later Remploy Limited: A Review of the Working of the Company During Its First Seven Years (March 1953), 47.

66. Ibid.

67. Report of the Committee of Inquiry on The Rebabilitation Training and Resettlement of Disabled Persons (Cmd. 9883) (November 1956), House of Commons Parliamentary Papers Online; Topliss, Provision for the Disabled, 55-57; Reiss, Blind Workers Against Charity, 138-140.

68. Report of the Royal Commission on the Law Relating to Mental Illness and Mental Deficiency (Cmd. 169) (May 1957), House of Commons Parliamentary Papers Online, 225-226.

69. TNA, LAB 20/173, NACED Sheltered Employment Committee, Employment of Persons Suffering from Psychiatric Disorders (S.E.C. 9).

70. Ibid.

71. TNA, LAB 20/173, Committee on Sheltered Employment, Undertakings Providing Employment for the Severely Disabled Other Than Those at Present Included in the Ministry of Labour and National Service Scheme of Grants S.E.C. 2 (1945).

72. Ibid.

73. TNA, LAB 20/1073, NACED Sheltered Employment Committee, Approved Arrangements Made by Local Authorities for Providing Sheltered 
Employment for Severely Disabled Sighted Persons (1965); TNA, LAB 20/1429, Department of Employment, Sheltered Employment: A Draft Consultative Document (October 1973), 21.

74. TNA, LAB 20/1073, NACED Sheltered Employment Committee, Provision of Sheltered Employment by Local Authorities and Voluntary Bodies: S.E.C. 111 (November 1965).

75. Mr. Fernyhough (9 July 1968), Hansard, vol. 768 c. 48 w.

76. Mr. Dudley Smith (30 July 1971), Hansard, vol. 822 cc. 180-1w

77. TNA, LAB 20/1429, DE, Sheltered Employment: A Draft Consultative Document (October 1973), 47.

78. Ibid.

79. TNA, BM 8/79, Remploy Limited, Minutes of the Three Hundred and Thirty-Eighth Meeting of the Board of Directors (19 February 1976).

80. Ibid.

81. Ibid.

82. Ibid.

83. TNA, BM 6/10, Remploy News, No. 63 (Autumn 1964).

84. TNA, BM 8/81, Remploy Limited, Managing Director Report No. 250 (March 1975).

85. TNA, BM 8/49, Remploy Limited, Minutes of the Three Hundred and Twenty-Fifth Meeting of the Board of Directors (19 December 1974).

86. TNA, BM 8/81, Remploy Limited, Personnel Director's Report No. 248 (January 1975); TNA BM 3/47, Remploy Limited, Report of a Mentally Disabled Teach-In (3 January 1975).

87. TNA, BM 8/49, Remploy Limited, Minutes of the Three Hundred and Twenty-Fifth Meeting of the Board of Directors (19 December 1974).

88. Ibid.

89. TNA, BM 10/48, Remploy Limited, Report of the Working Party on 'Objectives' \& Criteria of Success (Hailey Report) (July 1980).

90. Ibid., 26.

91. Ibid., 46.

92. Ibid., 28.

93. TNA, BM 3/70, Remploy Limited, Report of the Working Party on the Mix of Disabilities Employed by Remploy (March 1981).

94. Ibid.

95. Ibid.

96. Ibid.

97. Ibid.

98. Ibid. 
Open Access This chapter is licensed under the terms of the Creative Commons Attribution 4.0 International License (http://creativecommons.org/licenses/ by $/ 4.0 /$ ), which permits use, sharing, adaptation, distribution and reproduction in any medium or format, as long as you give appropriate credit to the original author(s) and the source, provide a link to the Creative Commons license and indicate if changes were made.

The images or other third party material in this chapter are included in the chapter's Creative Commons license, unless indicated otherwise in a credit line to the material. If material is not included in the chapter's Creative Commons license and your intended use is not permitted by statutory regulation or exceeds the permitted use, you will need to obtain permission directly from the copyright holder.

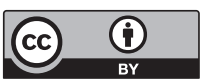

